\title{
Effects of vermicomposts and composts on plant growth in horticultural container media and soil
}

\author{
R. M. Atiyeh1', S. Subler'1, C. A. Edwards'1, G. Bachman², \\ J. D. Metzger ${ }^{2}$ and W. Shuster ${ }^{1}$ \\ 1 Soil Ecology Laboratory \\ 2 Dept. of Horticulture and Crop Sciences, The Ohio State University, 1735 Neil Avenue, \\ Columbus, Ohio 43210, USA
}

Accepted: 18. February 2000

\section{Summary}

Vermicomposts, which are produced by the fragmentation of organic wastes by earthworms, have a fine particulate structure and contain nutrients in forms that are readily available for plant uptake. In greenhouse trials, the growth of marigold and tomato seedlings, in a commercial horticultural potting medium (Metro-Mix 360), was enhanced significantly upon substitution of Metro-Mix 360 with $10 \%$ or $20 \%$ vermicomposted pig solids or vermicomposted food wastes, when all required nutrients were supplied. Same enhancement in marigold and tomato seedlings' growth occurred also upon substitution of Metro-Mix 360 with composted biosolids, but not with leaf compost. The shoot dry weights of raspberry plants, grown in a mineral soil mixed with vermicomposted pig wastes weighed more than those grown in unfertilized control soil, and were as great as those in soil receiving a complete fertilizer treatment. By comparison, raspberry shoot growth in soils amended with yard, leaf or bark composts, was poorer than that in the unfertilized control soil. Amending the soil with $4 \%$ chicken manure compost killed most of the raspberry plants. However, plant mortality was reduced and growth restored when the chicken manure compost was mixed with vermicomposted pig solids, but not with bark or yard composts. Plant growth in soils containing a mixture of chicken manure compost with $20 \%$ vermicomposted pig wastes was similar to that of plants grown in the unfertilized control. Our results showed that vermicomposts have the potential for improving plant growth when added to greenhouse container media or soil. However, there seem to be distinct differences

Corresponding author: Rola M. Atiyeh, e-mail: atiyeh.1@osu.edu 
between specific vermicomposts and composts in terms of their nutrient contents, the nature of their microbial communities, and their effects on plant growth.

Key words: Earthworms, organic wastes, vermicomposts, composts, plant growth

\section{Introduction}

With the progressive increase in the size of the world's population and the adoption of intensive animal husbandry production, large volumes of organic wastes produced all over the world are creating a serious disposal problem and a major source of environmental pollution. These wastes require large quantities of land for disposal, release odor and ammonia into the air, could contaminate groundwater with pollutants, and might present a health risk (Inbar et al. 1993). They can rarely be applied directly to the soil since they might damage soil fertility severely (Senesi 1989), and result in structural incompatibility, nitrogen immobilization, and phytotoxicity (Inbar et al. 1985). Some form of treatment of these wastes can make them suitable for land application and for safe disposal into the environment.

Composting, generally defined as the biological aerobic transformation of an organic byproduct into a different organic product that can be added to the soil without detrimental effects on crop growth (Baca et al. 1992), has been indicated as the most adequate method for pre-treating and managing organic wastes (Godden et al. 1986; Senesi 1989; Inbar et al. 1993; Eghball et al. 1997). In the process of composting, organic wastes are recycled into stabilized products that can be applied to the soil as an odorless and relatively dry source of organic matter, which would respond more efficiently and safely than the fresh material to soil organic fertility requirements. The conventional and most traditional method of composting consists of an accelerated biooxydation of the organic matter as it passes through a thermophilic stage $\left(45^{\circ}\right.$ to $65^{\circ} \mathrm{C}$ ) where microorganisms liberate heat, carbon dioxide and water (Dominguez et al. 1997). However, in recent years, researchers have become progressively interested in using another related biological process for stabilizing organic wastes, which does not include a thermophilic stage, but involves the use of earthworms for breaking down and stabilizing the organic wastes.

The ability of some earthworms to consume a wide range of organic residues such as sewage sludge, animal wastes, crop residues, and industrial refuse has been fully established (Mitchell et al. 1980; Edwards et al. 1985; Chan \& Griffiths 1988; Hartenstein \& Bisesi 1989). In the process of feeding, earthworms fragment the waste substrate, enhance microbial activity and the rates of decomposition of the material, leading to a composting or humification effect by which the unstable organic matter is oxidized and stabilized. The end product, commonly termed vermicompost and obtained as the organic wastes pass through the earthworm gut, is quite different from the parent waste material. Vermicomposts are finely divided peat-like materials with high porosity, aeration, drainage, and water-holding capacity (Edwards \& Burrows 1988). They have a vast surface area, providing strong absrobability and retention of nutrients (Shi-wei \& Fu-zhen 1991). Vermicomposts contain nutrients in forms that are readily taken up by the plants such as nitrates, exchangeable phosphorus, and soluble potassium, calcium, and magnesium (Edwards \& Burrows 1988; Orozco et al. 1996). 
Accordingly, vermicomposts should have a great potential in the horticultural and agricultural industries as media for plant growth.

There are only few research studies that have examined the responses of plants to the use or substitution of vermicomposts to soil or greenhouse container media (Chan \& Griffiths 1988; Edwards \& Burrows 1988; Wilson \& Carlile 1989; Mba 1996; Buckerfield \& Webster 1998). Most of these studies confirmed that vermicomposts have beneficial effects on plant growth. Vermicomposts, whether used as soil additives or as components of horticultural media, improved seed germination and enhanced rates of seedling growth and development.

Over the past three years, a comprehensive research program on vermicomposting has been developed at the Ohio State University. This has included experiments investigating the effects of vermicomposts on the germination, growth, flowering, and fruiting of vegetable plants such as bell peppers and tomatoes, as well as on a wide range of flowering plants including petunias, marigolds, bachelor's button, chrysanthemums, impatiens, sunflowers, and poinsettias. A consistent trend in all these growth trials has been that the best plant growth responses, with all needed nutrients supplied, occurred when vermicomposts constituted a relatively small proportion $(10 \%$ to $20 \%$ ) of the total volume of the container medium mixture, with greater proportions of vermicomposts in the plant growth medium not always improving plant growth (Subler et al. 1998). Some of the plant growth responses in horticultural container media, substituted with a range of dilutions of vermicomposts, were similar to those reported when composts were used instead (Shiralipour et al. 1992; Sikora \& Azad 1993).

However, composting and vermicomposting are quite distinct processes, particularly concerning the optimum temperatures for each process and the types of microbial communities that predominate during active processing (i.e. thermophilic bacteria in composting, mesophilic bacteria and fungi in vermicomposting). The wastes processed by the two systems are also quite different. Edwards and Burrows (1988) reported that vermicomposts have a much finer structure than composts and contain nutrients in forms that are readily available for plant uptake. There have also been reports by Krishnamoorthy and Vajrabhiah (1986) and Tomato and Galli (1995) of production of plant growth regulators in the vermicomposts. Therefore, we hypothesized that there should be considerable differences in the performances and effects of composts and vermicomposts on plant growth when used as soil amendments or as components of horticultural plant growth media.

\section{Materials and Methods}

We conducted two separate greenhouse studies to compare how vermicomposts and composts affect plant growth when used as substitutions in greenhouse container media or to soil. The basic chemical properties of all media used, the vermicomposts, and composts are summarized in Table 1.

The first plant growth trial was conducted in the Horticulture Department Greenhouse at the Ohio State University. In this trial, we compared the germination and growth of tomato ('Rutgers') and marigold ('Queen Sophia') seedlings in a commercial horticultural plant growth medium (Metro-Mix 360, Scotts, Marysville, OH) substituted with two types of vermicomposts (pig manure vermicompost and food wastes vermicompost) and two types of com- 
Table 1. Chemical properties of container media, vermicomposts and composts

\begin{tabular}{|c|c|c|c|c|c|c|c|c|}
\hline Medium & $\mathrm{pH}$ & $\begin{array}{l}\text { Conduc- } \\
\text { tivity }\end{array}$ & $\begin{array}{c}\text { Total } \\
\mathrm{N}\end{array}$ & $\underset{\mathrm{C}}{\text { Organic }}$ & $\begin{array}{c}\text { Total } \\
\mathrm{P}\end{array}$ & $\begin{array}{c}\text { Total } \\
\mathrm{K}\end{array}$ & $\mathrm{NH}_{4}-\mathrm{N}$ & $\mathrm{NO}_{3}-\mathrm{N}$ \\
\hline & & \multicolumn{5}{|c|}{ (mmhos/cm) - } & \multicolumn{2}{|c|}{$\mu g / g$} \\
\hline \multicolumn{9}{|c|}{ Metro-Mix } \\
\hline 360 & 5.9 & 1.35 & 0.43 & 31.78 & 0.15 & 1.59 & 93 & 77 \\
\hline \multicolumn{9}{|c|}{ Vermicomposts } \\
\hline \multicolumn{9}{|c|}{ Pig solids } \\
\hline (VC) & 5.3 & 4.80 & 2.36 & 43.8 & 4.5 & 0.4 & 123 & 4525 \\
\hline \multicolumn{9}{|c|}{ Food wastes } \\
\hline (OS) & 7.3 & 3.30 & 1.80 & 34.0 & 0.4 & 1.1 & $<14$ & 665 \\
\hline \multicolumn{9}{|l|}{ Composts } \\
\hline \multicolumn{9}{|l|}{ Biosolids } \\
\hline \multicolumn{9}{|c|}{ Leaf wastes } \\
\hline (LEAF) & 8.0 & 1.75 & 1.16 & 35.3 & 0.2 & 0.6 & 32 & 188 \\
\hline \multicolumn{9}{|c|}{ Yard wastes } \\
\hline (YARD) & 8.1 & 1.29 & 0.95 & 33.5 & 0.1 & 0.5 & 24 & 15 \\
\hline \multicolumn{9}{|c|}{ Bark wastes } \\
\hline (BARK) & 7.1 & 0.34 & 0.81 & 70.3 & 0.2 & 0.3 & 18 & 187 \\
\hline \multicolumn{9}{|c|}{ Chicken } \\
\hline$(\mathrm{CC})$ & 6.8 & 2.84 & 4.63 & 51.7 & 3.2 & 3.3 & 4637 & 321 \\
\hline
\end{tabular}

posts (composted biosolids and leaf compost). Metro-Mix 360 is prepared from vermiculite, Canadian sphagnum peat moss, bark ash and sand, and contains a starter nutrient fertilizer in its formulation. The pig manure-based vermicompost was provided by Vermicycle Organics, Inc. (Charlotte, North Carolina) and consisted of separated pig solids processed by earthworms (Eisenia spp.) in indoor beds. The food waste-based vermicompost was provided by Oregon Soil Corporation (Portland, Oregon) and consisted of food wastes processed by earthworms in a continuous-flow reactor. The biosolids compost, 'Com-Til', was provided by the city of Columbus (Ohio), and the leaf compost from Kurtz Bros., Inc. (Groveport, Ohio).

We germinated and grew tomato and marigold seedlings in 200 cell plug trays filled with various mixtures of vermicomposts and composts, with Metro-Mix 360. The media mixtures included Metro-Mix 360 as a control, Metro-Mix 360 substituted with $10 \%$ or $20 \%$ (by volume) respectively of either vermicomposts (vermicomposted pig wastes or vermicomposted food wastes) or composts (biosolids or leaf composts). There were nine different container mixes (Table 2), with four plug trays per mix. All trays were watered daily with 20-10-20 $(150 \mathrm{ppm} \mathrm{N})$ Peters Professional nutrient solution. Peters Professional is a water-soluble fertilizer that is recommended for continuous liquid feed programs of plants, and contains all macro and micronutirents that are essential for plant growth. The plants were sown and grown on for four weeks. Five plants from each mixture were then harvested randomly 3, 7, 14, and 21 days after germination. The average amounts of total leaf chlorophyll contents of plants in each mixture was measured following Moran's (1982) method, using N,N-dimethylformamide (DMF) as the solvent to extract chlorophyll. The average dry shoot weight in each potting mixture was also determined. Also as part of this study, we assessed the physiological profile of the microbial community in each of the potting mixture, using direct incubation of dilutions of the pot- 
ting mixtures in BIOLOG GN plates containing 92 different carbon sources (Garland \& Mills 1991). Some of these carbon sources, such as simple sugars, are readily utilized by many different microbial species, but other more complex substrates may only be broken down and utilized by particular species. Therefore, the entire microbial community in a sample will be able to utilize each individual substrate to a greater or lesser degree, depending on the overall species composition and activity of the microbial community. It is then possible to take the sum of all of the activities for the substrates and use it as an overall index of microbial activity in each of the potting mixtures.

In the second plant growth trial conducted at The Ohio State University Research Center in Piketon, we evaluated two vermicomposts and four composts as soil amendments in a pot experiment growing raspberry plants. We grew 'Heritage' raspberry plants for three months in the greenhouse in 4 L pots containing mineral soil substituted with $20 \%$ (by volume) of vermicompost (vermicomposted pig wastes or vermicomposted food wastes) or compost (leaf, yard waste, hardwood bark, or chicken manure compost), or a combination of vermicomposts and composts. The pig waste vermicompost, the food waste vermicompost and the leaf compost were the same as the ones described in the growth study described earlier. The yard waste and hardwood bark composts, similar to the leaf compost, were composted in windrows and obtained from Kurtz Bros., Inc. (Groveport, Ohio), while the chicken manure compost was obtained from Nature Pure, Inc. (Mansfield, Ohio). Plants in both fertilized and unfertilized pots that received no organic amendments served as controls. There were 12 different soil amendment mixtures (Table 2) with three replicate pots per mixture. Raspberry plants were grown for three months, then harvested and their total dry shoot weights measured.

Data were analyzed statistically by one-way ANOVA in a general linear model using SAS (SAS Institute Inc. 1990). The means of all plant growth parameters for each potting mixture at each growth stage were separated statistically using Tukey's multiple range. Significance was defined as $\mathrm{P} \leq 0.05$.

Table 2. Potting mixtures used in the study

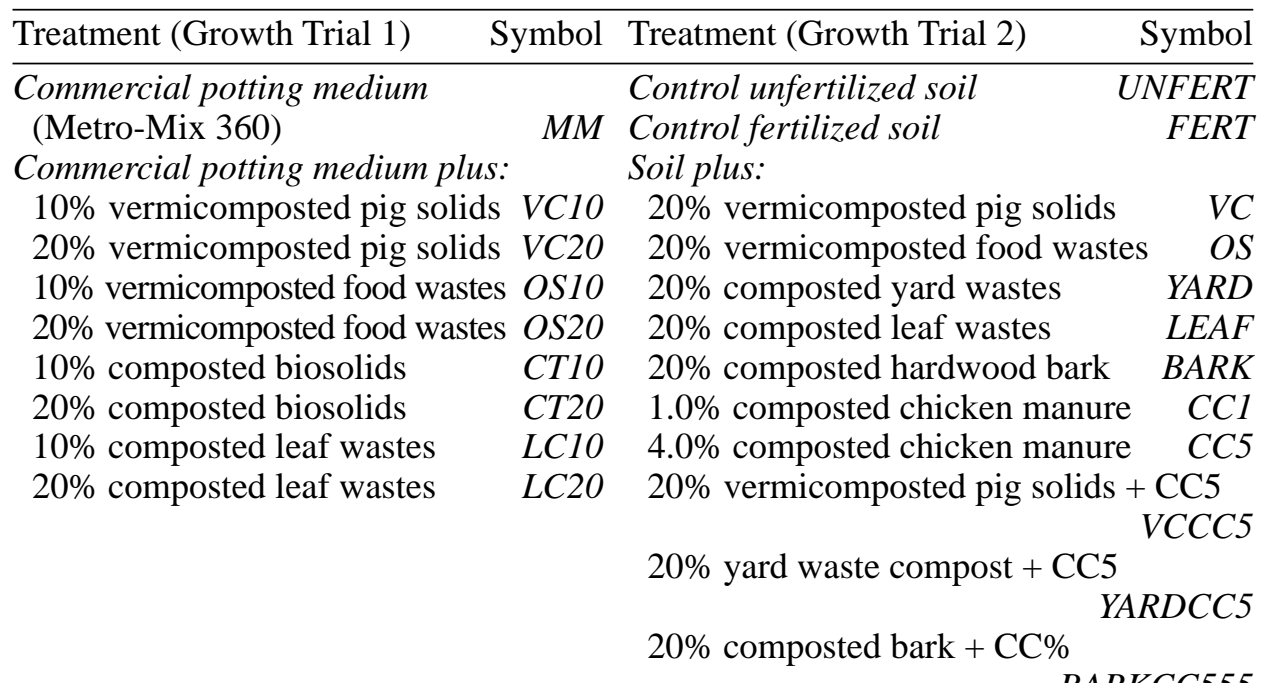

BARKCC555 


\section{Results}

When the chemical properties of vermicomposts and composts were compared (Table 1), we found that there was a tendency for the vermicomposts to have a slightly lower $\mathrm{pH}$, lower concentrations of ammonium-nitrogen, and higher concentrations of nitrate-nitrogen than many of the composts. However, overall, there was a considerable overlap between both the nutrient content and the form of nutrients in vermicomposts and composts, making it hard to predict the potential plant growth responses to these materials based solely on the results of such chemical analyses. To obviate the nutrient effect, in the greenhouse study with tomato and marigold, all essential mineral nutrients were supplied daily.

In the first growth study, the marigold seedlings grown in the potting mixtures with $20 \%$ biosolids compost were damaged and were therefore excluded from the study. Differences in the total leaf chlorophyll concentrations were observed only in the marigold seedlings, and this difference occurred for only one week after germination (Fig.1). Marigold seedlings grown in container media with $10 \%$ or $20 \%$ vermicomposted pig solids or with $10 \%$ vermicomposted food wastes, contained more chlorophyll than plants grown in Metro-Mix control or any of the Metro-Mix/compost mixtures. However, these differences tended to decrease as the plants grew. Three weeks after germination, the shoot dry weights of marigold plants grown in potting media, substituted with either vermicomposts or with biosolids composts, weighed more than the marigolds grown in the Metro-Mix control (Fig. 2). On the other hand, the Metro-Mix/leaf compost mixtures produced poorer marigold growth than the controls or any other potting mixture.

Tomato seedlings grown in the Metro-Mix/pig waste vermicomposts at the $10 \%$ rate weighed significantly more, three weeks after germination, than the seedlings grown in Metro-Mix alone and supplied with all needed mineral nutrients (Fig. 3).

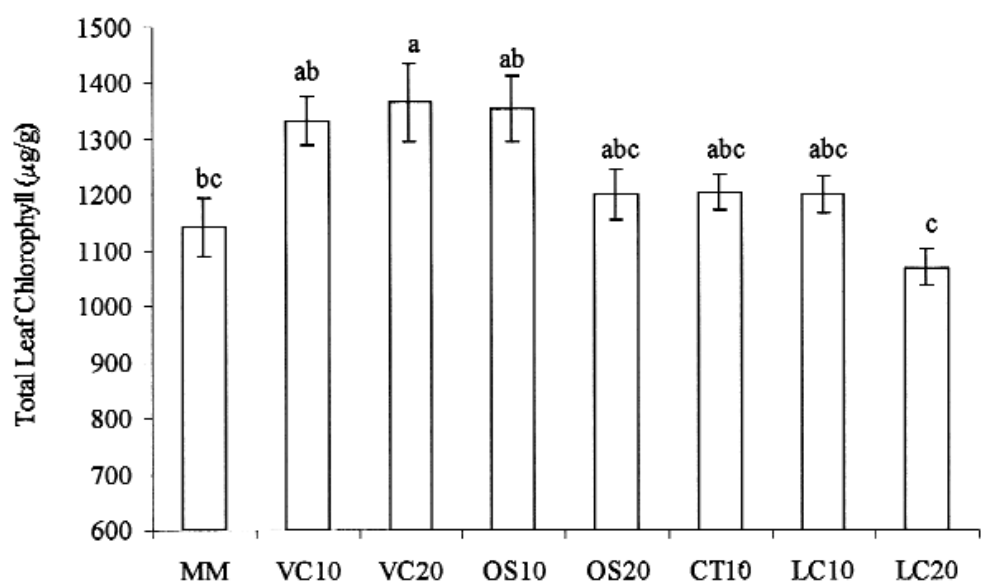

Fig. 1. Chlorophyll content of marigold leaves (mean \pm standard error) seven days after germination in a standard commercial potting medium (MM) substituted with $10 \%$ or $20 \%$ (by volume) of pig waste (VC) or food waste (OS) vermicomposts, or biosolids (CT) or leaf (LC) composts, and supplied with all needed nutrients. Columns followed by the same letter are not significantly different at $\mathrm{P} \leq 0.05$ 


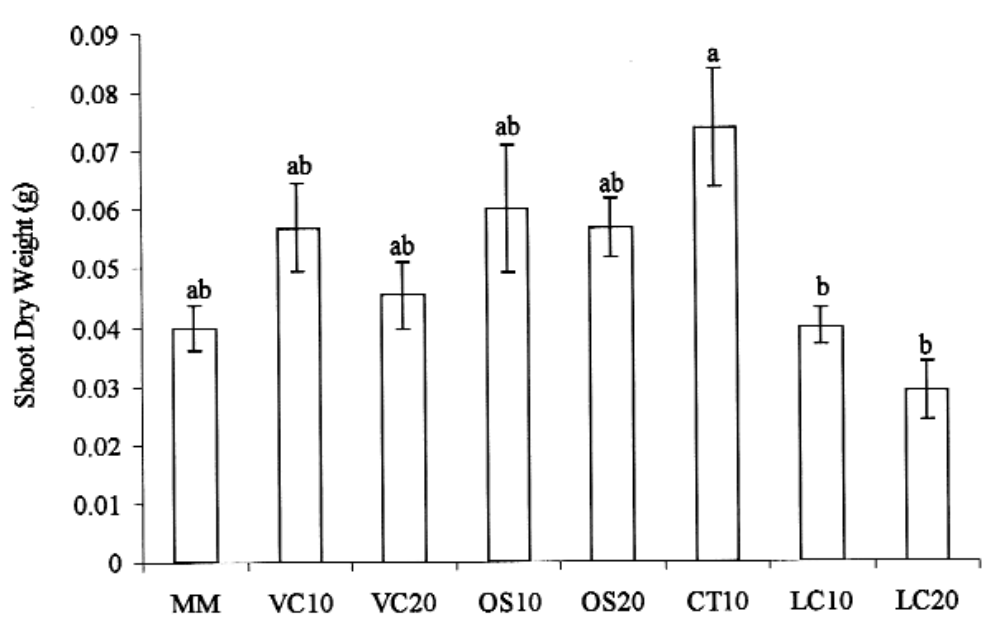

Fig. 2. Shoot dry weights (mean \pm standard error) of marigold plants three weeks after germination in a standard commercial potting medium (MM) substituted with $10 \%$ or $20 \%$ (by volume) of pig waste (VC) or food waste (OS) vermicomposts, or biosolids (CT) or leaf (LC) composts, and supplied with all needed nutrients. Columns followed by the same letter are not significantly different at $\mathrm{P} \leq 0.05$

Potting mixtures containing $10 \%$ food waste vermicompost or $20 \%$ pig waste vermicompost increased the dry shoot weights of tomato seedlings only slightly, compared to the Metro-Mix control, whereas both concentrations of the leaf compost reduced the shoot dry weights of the seedlings. The greatest shoot dry weight increase, among all the Metro-Mix/amendment mixtures, occurred with the substitution of $10 \%$ and $20 \%$ biosolids compost.

All potting mixtures containing vermicomposts had a significantly greater cumulative microbial activity than the Metro-Mix control, or any of the compost-containing mixtures (Fig. 4).

The growth of raspberry plants differed significantly among the different soil mixtures used (Fig. 5). The shoots of plants grown in soil substituted with pig waste vermicompost were as big as those grown in soil that had received a complete fertilizer treatment, and weighed significantly more (1.8 times) than those in the unfertilized control soil. Mixtures of soil with food waste vermicompost or with $1 \%$ chicken manure compost had much smaller effects on plant growth, to a level similar to those grown in the unfertilized control soil. Amendments of soil with $20 \%$ yard, leaf, or bark composts resulted in poorer plant growth compared to the unamended, unfertilized control soil. Although the addition of small quantities of chicken manure compost ( $1 \%$ by volume) to the soil had little effect on raspberry plant growth, incorporation of larger quantities ( $4 \%$ by volume) of chicken manure compost into the soil had a detrimental effect on the plants. This deleterious effect of large concentrations of chicken manure compost was diminished considerably when the chicken manure compost was mixed with $20 \%$ vermicomposted pig manure, but not when mixed with yard wastes compost or bark wastes compost. Plants in pots containing vermicomposted pig solids with $4 \%$ composted chicken manure grew as well as the plants in the unfertilized control soil (Fig. 5). 


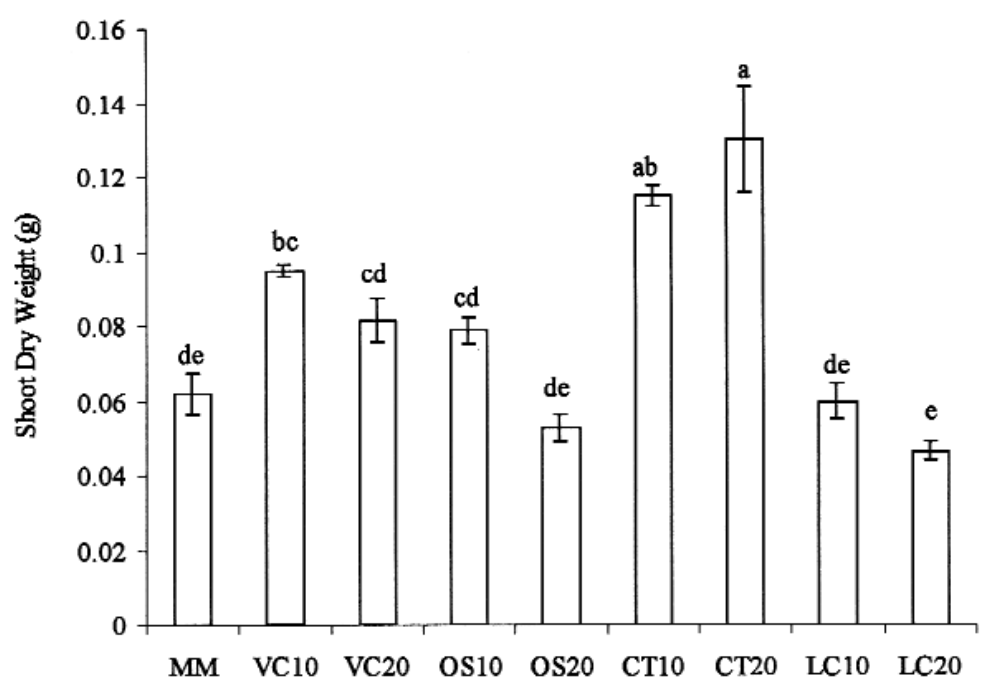

Fig. 3. Shoot dry weights (mean \pm standard error) of tomato plants three weeks after germination in a standard commercial potting medium (MM) substituted with $10 \%$ or $20 \%$ (by volume) of pig waste (VC) or food waste (OS) vermicomposts, or biosolids (CT) or leaf (LC) composts, and supplied with all needed nutrients. Columns followed by the same letter are not significantly different at $\mathrm{P} \leq 0.05$

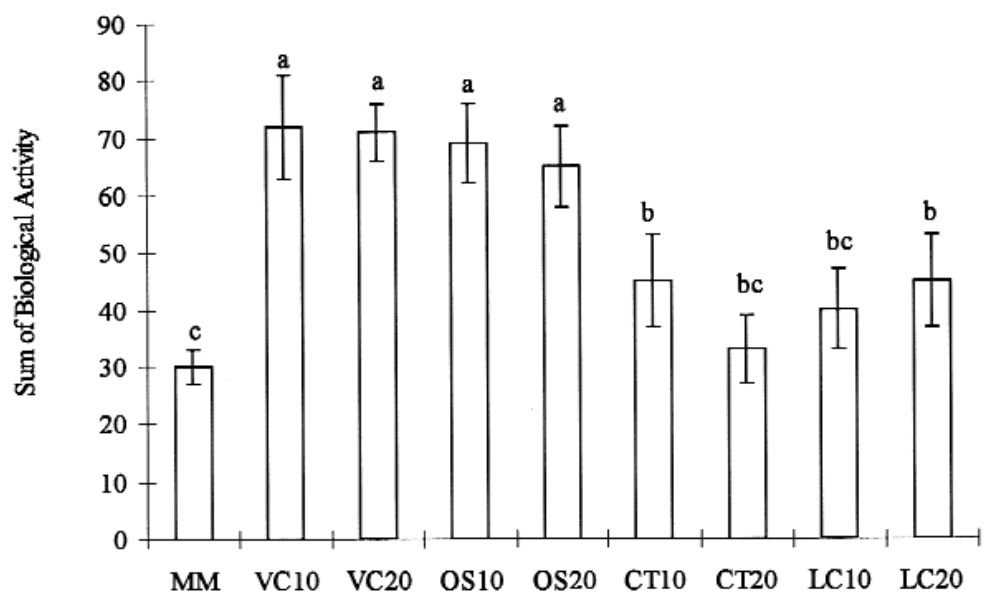

Fig. 4. Microbial activity index (mean \pm standard error) in a standard commercial potting medium (MM) substituted with $10 \%$ or $20 \%$ (by volume) of pig waste (VC) or food waste (OS) vermicomposts, or biosolids (CT) or leaf (LC) composts. Columns followed by the same letter are not significantly different at $\mathrm{P} \leq 0.05$ 


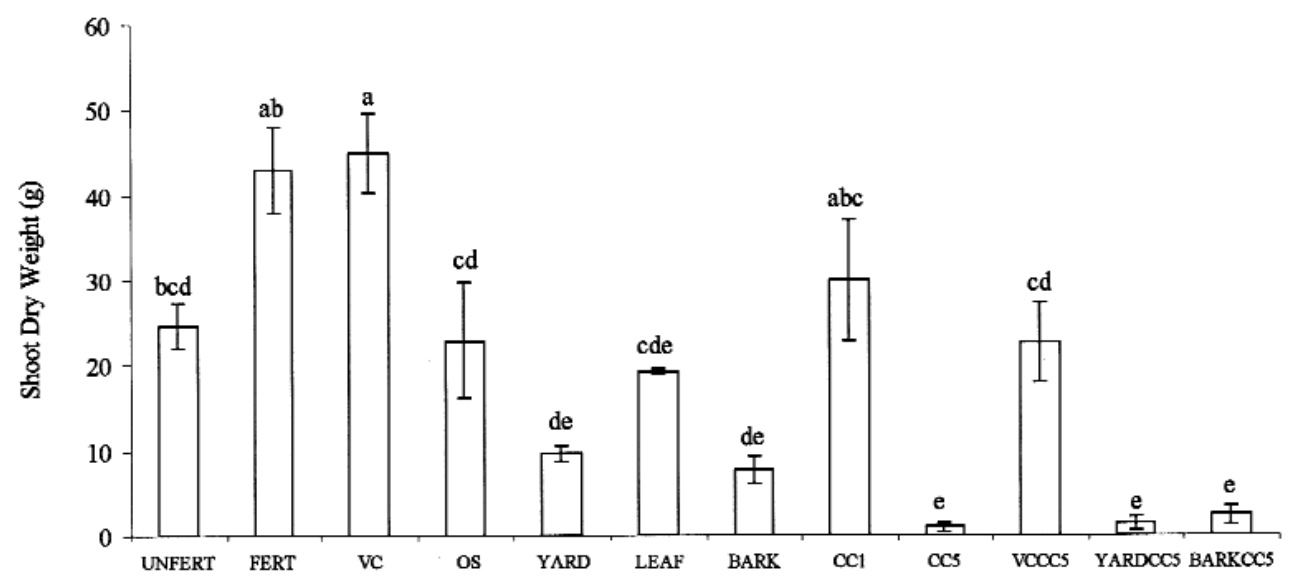

Fig. 5. Shoot dry weights (mean \pm standard error) of raspberry plants grown for three months in soil mixed with vermicomposts $(\mathrm{VC}=$ vermicomposted pig solids; $\mathrm{OS}=$ vermicomposted food wastes; VCCC5 $=$ vermicomposted pig solids plus $4 \%$ composted chicken manure) or composts (YARD $=$ composted yard wastes; $\mathrm{LEAF}=\mathrm{com}$ posted leaf wastes; BARK $=$ composted hardwood bark; $\mathrm{CC} 1=1 \%$ composted chicken manure; $\mathrm{CC} 5=4 \%$ composted chicken manure; YARDCC5 $=$ yard compost plus $4 \%$ composted chicken manure; BARKCC $5=$ bark compost plus $4 \%$ composted chicken manure). Unfertilized (UNFERT) and fertilized (FERT) soils served as control. Columns followed by the same letter are not significantly different at $\mathrm{P} \leq 0.05$

\section{Discussion}

These experiments, together with others reported in the literature, demonstrate that vermicomposts have considerable potential for improving plant growth significantly, when used as components of horticultural soil or container media. Nevertheless, there appear to be major differences between the effects of the vermicomposts and composts that were used in our study, in terms of their influence on plant growth, depending upon the source of the parent waste material used in their production. These differences in growth responses could be due in part to fundamental differences between the composting and vermicomposting processes which use quite different microbial communities, with composting tending to result in the release of mineral nitrogen in the ammonium form, whereas vermicomposting releases most of the nitrogen in the nitrate form (Edwards \& Burrows 1988), the form readily available for plant uptake.

From the experiments that we have described here, the addition of pig waste vermicompost consistently outperformed the addition of most of the composts, with the exception of biosolids compost, and other vermicomposts that we have investigated in terms of its ability to enhance plant growth. Incorporation of $10 \%$ or $20 \%$ vermicomposted pig solids into a standard commercial horticultural potting medium (Metro-Mix 360) enhanced the growth of marigold and tomato seedlings significantly as compared to the Metro-Mix 36 alone, even when all required mineral nutrients were supplied.

Many factors, which impact plant growth, could be responsible for the enhanced 
plant growth after substituting the container medium with the pig solids vermicompost or with the composted biosolids. Goh and Haynes (1977) reported that plant growth is generally optimized when the $\mathrm{pH}$ is between 5.0 and 6.5. The vermicomposted pig solids had a $\mathrm{pH}$ of 5.3, whereas the food waste vermicompost and all the composts used had an alkaline $\mathrm{pH}$ (between 6.8 and 8.1). It is possible that the high $\mathrm{pH}$ of these materials have raised the $\mathrm{pH}$ of the container medium to a degree proportional to the amount of vermicompost or compost incorporated (Gallardo-Lara \& Nogales 1987), resulting in a reduced plant growth as compared to that in media with vermicomposted pig wastes. The improvements in plant growth could also be due to differences in the mineral element contents of the substrates, vermicomposts, and composts. Vermicomposted pig solids contained large concentrations of nitrates, thus increasing plant growth significantly to a level comparable to that of fertilized soil in the raspberry study. Composted biosolids also contained high levels of ammonium, resulting in a large increase in the growth of tomato plants in the greenhouse container medium study. The decline in plant growth upon substitution of the soil or container medium with yard, leaf, and bark composts, could possibly be related to the stability or maturity of these composts, rather than their mineral nutrient content. Saviozzi et al. (1988) reported that organic wastes, in order to be compatible with agricultural uses and to avoid adverse effects on plant growth, have to be transformed into a humus-like material and be sufficiently stabilized. The detrimental effect of large concentrations of chicken manure compost on the growth of raspberry plants was probably due to the high ammonium content in the chicken manure, which severely burned the plant roots. What is of interest was the ability of vermicompost, but not any of the composts, to diminish this detrimental effect. This indicates that the vermicompost did not have a diluting effect. Rather, it has some beneficial buffering capability such as enhancing nitrification, associated with increased microbial activity, which could have ameliorated the plant damage caused by excess chicken manure compost.

Although this study focuses more on the effects of vermicomposts and composts on plant growth rather than on the causes leading to these effects, our results showed distinct differences in the activity of the microbial communities in container media to which either vermicomposts or composts have been added. This may be a consequence of the very different biochemical processes that lead to the production of vermicompost and compost. The active phase of composting being characterized by thermophilic bacteria, whereas the active phase of vermicomposting is characterized by mesophilic bacteria and fungi which are stimulated by the activity of earthworms. It is therefore possible that the differences in plant growth between vermicomposts and composts may not simply be a function of the differences in their nutritional content, especially in the first greenhouse study with all treatments supplied daily with all needed mineral nutrients. It seems probable that there are other inputs, such as increased enzymatic activity and the presence of beneficial microorganisms or biologically active plant growth influencing substances, that might be involved (Grappelli et al. 1987; de Brito Alvarez et al. 1995; Tomati \& Galli 1995).

In conclusion, vermicomposts have the potential for improving plant growth when added to greenhouse container media or soil. The optimal plant growth in our study, which was conducted only over a short period of time, was in pots containing pig manure vermicompost or composted biosolids. Our results also showed distinct differences between specific vermicomposts and composts in terms of their nutrient contents, the nature of their microbial communities, and their effects on plant growth. We 
have current research studies investigating more in depth the differences between vermicomposts and composts, and looking into the mechanisms by which both vermicomposts and composts can influence plant growth responses.

\section{References}

Baca, M.T., Fornasier, F., de Nobili, M. (1992) Mineralization and humification pathways in two composting processes applied to cotton wastes. Journal of Fermentation and Bioengineering 74, 179-184.

de Brito Alvarez, M. A., Gagne, S., Antoun, H. (1995) Effect of compost on rhizosphere microflora of the tomato and on the incidence of plant-growth promoting rhizobacteria. Applied and Environmental Microbiology 61, 194-199.

Buckerfield, J. C., Webster, K. A. (1998) Worm-worked waste boosts grape yields: prospects for vermicompost use in vineyards. Australian and New Zealand Wine Industry Journal 13, 73-76.

Chan, P. L. S., Griffiths, D. A. (1988) The vermicomposting of pre-treated pig manure. Biological Wastes 24, 57-69.

Dominguez, J., Edwards, C.A., Subler, S. (1997) A comparison of vermicomposting and composting. BioCycle 38, 57-59.

Edwards, C. A., Burrows, I. (1988) The potential of earthworm composts as plant growth media. In: Edwards, C. A., Neuhauser, E. (eds) Earthworms in Waste and Environmental Management. SPB Academic Press, The Hague, The Netherlands, pp. 21-32.

Edwards, C. A., Burrows, I., Fletcher, K. E., Jones, B.A. (1985) The use of earthworms for composting farm wastes. In: Gasser, J. K. R. (ed) Composting Agricultural and Other Wastes. Elsevier, London and New York, pp. 229-241.

Eghball, B., Power, J.F., Gilley, J.E., Doran, J.W. (1997) Nutrient, carbon, and mass loss during composting of beef cattle feedlot manure. Journal of Environmental Quality 26, 189-193.

Gallardo-Lara, F., Nogales, R. (1987) Effect of the application of town refuse compost on the soil-plant system: a review. Biological Wastes 19, 35-62.

Garland, J.L., Mills, A.L. (1991) Classification and characterization of heterotrophic microbial communities on the basis of patterns of community-level sole-carbon-source utilization. Applied and Environmental Microbiology 57, 2351-2359.

Godden, B., Penninckx, M.J., Castille, C. (1986) On the use of biological and chemical indexes for determining agricultural compost maturity: extension to the field scale. Agricultural Wastes 15, 169-178.

Goh, K.M., Haynes, R.J. (1977) Evaluation of potting media for commercial nursery production of container grown plants. New Zealand Journal of Agricultural Research 20, 363-370.

Grappelli, A., Galli, E., Tomati, U. (1987). Earthworm casting effect on Agaricus bisporus fructification. Agrochimica 21, 457-462.

Hartenstein, R., Bisesi, M. S. (1989) Use of earthworm biotechnology for the management of effluents from intensively housed livestock. Outlook on Agriculture 18, 3-7.

Inbar, Y., Chen, Y., Hadar, Y. (1985) The use of composted slurry produced by methanogenic fermentation of cow manure as growth media. Acta Horticulturae 172, 75-82.

Inbar, Y., Hadar, Y., Chen, Y. (1993) Recycling of cattle manure: the composting process and characterization of maturity. Journal of Environmental Quality 22, 857-863.

Krishnamoorthy, R.V., Vajrabhiah, S.N. (1986) Biological activity of earthworm casts: an assessment of plant growth promoter levels in casts. Proceedings of the Indian Academy of Sciences (Animal Science) 95, 341-351.

Mba, C. C. (1996) Treated-cassava peel vermicomposts enhanced earthworm activities and cowpea growth in field plots. Resources, Conservation and Recycling 17, 219-226. 
Mitchell, M. J., Hornor, S. G., Abrams, B. I. (1980) Decomposition of sewage sludge in drying beds and the potential role of the earthworm, Eisenia foetida. Journal of Environmental Quality 9, 373-378.

Moran, R. (1982) Formulae for determination of chlorphyllous pigments extracted with N,Ndimethylformamide. Plant Physiology 69, 1376-1381.

Orozco, F. H., Cegarra, J., Trujillo, L. M., Roig, A. (1996) Vermicomposting of coffee pulp using the earthworm Eisenia fetida: effects on $\mathrm{C}$ and $\mathrm{N}$ contents and the availability of nutrients. Biology and Fertility of Soils 22, 162-166.

SAS Institute (1990) SAS Procedures Guide, Version 6. $3^{\text {rd }}$ edition. SAS Institute, Cary.

Saviozzi, A., Levi-Minzi, R., Riffldi, R. (1988) Maturity evaluation of organic wastes. BioCycle 29, 54-56.

Senesi, N. (1989) Composted materials as organic fertilizers. The Science of the Total Environment 81/82, 521-542.

Shiralipour, A., McConnell, D. B., Smith, W.H. (1992) Uses and benefits of MSW compost: a review and an assessment. Biomass and Bioenergy 3, 267-279.

Shi-wei, Z., Fu-zhen, H. (1991) The nitrogen uptake efficiency from ${ }^{15} \mathrm{~N}$ labeled chemical fertilizer in the presence of earthworm manure (cast). In: Veeresh, G. K., Rajagopal, D., Viraktamath, C. A. (eds) Advances in Management and Conservation of Soil Fauna. Oxford and IBH publishing Co., New Delhi, Bombay, pp. 539-542.

Sikora, L.J., Azad, M.I. (1993) Effect of compost-fertilizer combination on wheat yields. Compost Science and Utilization 1, 93-96.

Subler, S., Edwards, C. A., Metzger, J. (1998) Comparing composts and vermicomposts. BioCycle 39, 63-66.

Tomati, U., Galli, E. (1995) Earthworms, soil fertility and plant productivity. Acta Zoologica Fennica 196, 11-14.

Wilson, D. P., Carlile, W. R. (1989) Plant growth in potting media containing worm-worked duck waste. Acta Horticulturae 238, 205-220. 